\title{
Article \\ A Novel Pear Scab (Venturia nashicola) Resistance Gene, Rvn3, from Interspecific Hybrid Pear (Pyrus pyrifolia $\times$ P. communis)
}

\author{
Sewon Oh, Hyeondae Han and Daeil Kim *D \\ Department of Horticulture, Chungbuk National University, Cheongju 28644, Korea; \\ oseng1234@cbnu.ac.kr (S.O.); hhd0916@cbnu.ac.kr (H.H.) \\ * Correspondence: dkpomo@cbnu.ac.kr; Tel.: +82-43-261-2527
}

Citation: Oh, S.; Han, H.; Kim, D.

A Novel Pear Scab (Venturia nashicola) Resistance Gene, Rvn3, from Interspecific Hybrid Pear (Pyrus pyrifolia $\times$ P. communis). Plants 2021 10, 2632. https://doi.org/10.3390/ plants10122632

Academic Editor: Yong-Gu Cho

Received: 29 October 2021

Accepted: 27 November 2021

Published: 30 November 2021

Publisher's Note: MDPI stays neutral with regard to jurisdictional claims in published maps and institutional affiliations.

Copyright: (c) 2021 by the authors. Licensee MDPI, Basel, Switzerland. This article is an open access article distributed under the terms and conditions of the Creative Commons Attribution (CC BY) license (https:// creativecommons.org/licenses/by/ $4.0 /)$.

\begin{abstract}
Asian pear scab is a fungal disease caused by Venturia nashicola. The identification of genes conferring scab resistance could facilitate the breeding of disease-resistant cultivars. Therefore, the present study aimed to identify a scab-resistance gene using an interspecific hybrid population $(($ Pyrus pyrifolia $\times$ P. communis $) \times$ P. pyrifolia $)$. Artificial inoculation of $V$. nashicola was carried out for two years. The segregation ratio (1:1) of resistant to susceptible individuals indicated that resistance to $V$. nashicola was inherited from P. communis and controlled by a single dominant gene. Based on two years phenotypic data with the Kruskal-Wallis test and interval mapping, 12 common markers were significantly associated with scab resistance. A novel scab resistance gene, Rvn3, was mapped in linkage group 6 of the interspecific hybrid pear, and co-linearity between Rvn3 and one of the apple scab resistance genes, Rvi14, was confirmed. Notably, an insertion in pseudo-chromosome 6 of the interspecific hybrid cultivar showed homology with apple scab resistance genes. Hence, the newly discovered Rvn3 was considered an ortholog of the apple scab resistance gene. Since the mapping population used in the present study is a pseudo- $\mathrm{BC}_{1}$ population, pyramiding of multiple resistance genes to pseudo- $\mathrm{BC}_{1}$ could facilitate the breeding of pear cultivars with durable resistance.
\end{abstract}

Keywords: disease resistance; genetic linkage map; InDel; ortholog; single dominant gene

\section{Introduction}

Venturia species are a threat to stable pear (Pyrus spp.) production; they infect the pear leaves, branches, and fruits leading to defoliation and poor fruit quality. While fungicides restrict Venturia species infection, they increase management costs in pear orchards and are ineffective against the fungicide-resistant strains. Therefore, breeding a scab-resistant pear cultivar is a fundamental solution to Venturia species infection.

$V$. nashicola and $V$. pirina are causes of pear scab [1,2]; V. nashicola only infects Asian pears (P. pyrifolia, $P$. ussuriensis, and P. bretschneideri), while $V$. pirina is only pathogenic to European pears (P. communis). It is also well known that the Japanese indigenous pear cultivar 'Kinchaku' has been shown to be resistant to $V$. nashicola.

According to pathogenic characteristics, Abe et al. [3] revealed that resistance to $V$. nashicola is controlled by a single dominant gene. However, other studies have shown that multiple resistance $(R)$ genes may be associated with pear scab resistance, and the genetic location of the $R$ gene may differ depending on the resistant host. Terakami et al. [4] identified an $R$ gene (Vnk) for $V$. nashicola, which is located in linkage group (LG) 1 of the indigenous pear (P. pyrifolia cv. Kinchaku). Besides, Cho et al. [5] reported Rvn2, another $R$ gene to $V$. nashicola, in LG13 of an interspecific hybrid pear [(P. pyrifolia $\times P$. ussuriensis $)$ $\times P$. communis]. They also developed cleaved amplified polymorphic sequence markers linked to the Rvn2. In European pears attacked by $V$. pirina, Pierantoni et al. [6] identified two major quantitative trait loci (QTLs) associated with $V$. pirina resistance in the LG3 and LG7 of 'Abbè Fétel' (P. communis). Bouvier et al. [7] also identified a new Rvp1 resistant to $V$. pirina in LG2 of 'Navara' (P. communis). 
Since pear and apple belong to the same subfamily Pomoideae in Rosaceae, genome synteny has been frequently observed [8]. The genome sequencing of pear and apple revealed an almost equal number of genes in the two genomes $[9,10]$. Further, a comparison between pear and apple genomes has accelerated the identification of genes controlling traits of interest; particularly, the pear and apple scab $(V$. inaequalis) $R$ genes located in the same homologous LG [4,7]. Terakami et al. [4] also suggested a comparison of the genetic location in LG could help understand genome synteny in scab resistance between pear and apple.

In a previous study, an interspecific hybrid pear, 'Greensis', was selected from seedlings derived from a cross between 'Whangkeumbae' (P. pyrifolia) and 'Bartlett' (P. communis) [11]. Because the paternal parent 'Bartlett' has resistance to V. nashicola [12], 'Greensis' displayed scab resistance when artificially inoculated with $V$. nashicola [11]. Therefore, we hypothesized that a mapping population derived from a cross with 'Greensis' would be ideal for identifying the $R$ gene against $V$. nashicola. Herein, we performed an association mapping study to explore novel $R$ genes, which confer resistance to $V$. nashicola using a pseudo- $\mathrm{BC}_{1}$ population derived from a cross between scab-resistant 'Greensis' [11] and scab-susceptible 'Whasan' [13].

\section{Results}

\subsection{Evaluation of Pear Scab Resistance}

Six weeks after the inoculation of $V$. nashicola, there were no disease symptoms on the leaves of the scab-resistant cultivar, 'Greensis'. On the other hand, the inoculated leaves of the susceptible cultivar, 'Whasan', were wrinkled and chlorosis with sporulation was observed. Based on the Shay and Hough [14] and Chevalier et al. [15] studies, disease symptoms of the pseudo- $\mathrm{BC}_{1}$ individuals were divided into five classes. Thirty-nine and thirty-eight out of ninety-three pseudo- $\mathrm{BC}_{1}$ individuals showed resistance (hypersensitive response (HR) and chlorotic reaction) in 2016 and 2018, respectively. The remaining individuals showed sporulation and were regarded as susceptible individuals. The segregation ratios of scab-resistant to scab-susceptible individuals in 2016 and 2018 fitted the expected ratio (1:1) at a significance level of 5\% (Table 1).

Table 1. Segregation of scab-resistant and scab-susceptible individuals in 'Greensis' $\times$ 'Whasan' after artificial inoculation of Venturia nashicola in 2016 and 2018.

\begin{tabular}{|c|c|c|c|c|c|}
\hline \multirow{2}{*}{ Year } & \multicolumn{2}{|c|}{ No. of Individuals } & \multirow{2}{*}{$\begin{array}{c}\text { Expected } \\
\text { Segregation Ratio }\end{array}$} & \multirow{2}{*}{$\chi^{2}$-Value } & \multirow{2}{*}{$p$} \\
\hline & Resistant & Susceptible & & & \\
\hline 2016 & 39 & 54 & $1: 1$ & 2.42 & 0.12 \\
\hline 2018 & 38 & 55 & 1:1 & 3.11 & 0.08 \\
\hline
\end{tabular}

\subsection{Construction of Genetic Linkage Maps}

Figures S1 and S2 show genetic linkage maps of 'Greensis' and 'Whasan', respectively. These two genetic linkage maps consist of 17 LGs corresponding to the basic chromosome number of pear. The 17 LGs of 'Greensis' and 'Whasan' genetic maps were designated as G1 to G17 and W1 to W17, respectively. The genotyping-by-sequencing (GBS)-single nucleotide polymorphisms (SNPs) were grouped in the same homologous LG according to their chromosomal location. Each LG of 'Greensis' and 'Whasan' maps partially represent each pseudo-chromosome. The genetic map of 'Greensis' consisted of 673 GBS-SNPs and 52 simple sequence repeats (SSRs), which were distributed at a genetic distance of 1284.3 cM with an average marker density of $1.90 \mathrm{cM}$ (Table S1). In the genetic map of 'Whasan', 630 GBS-SNPs and 27 SSRs were distributed at a genetic distance of $1612.4 \mathrm{cM}$ with an average marker density of $2.59 \mathrm{cM}$ (Table S2). The genetic maps of 'Greensis' and 'Whasan' covered 73.3 and $68.7 \%$ of the pseudo-chromosomes of pear, respectively. 


\subsection{Identification of a Novel Scab Resistance Gene}

Based on the Kruskal-Wallis test and interval mapping results, 14 loci were identified as significant markers associated with scab resistance. The logarithm of odd (LOD) thresholds in G6 were 1.6 and 1.5 in 2016 and 2018, respectively $(p=0.05)$. All 14 loci had a segregation type of $\langle 1 \mathrm{~m} \times 1 \mathrm{l}\rangle$ in 'Greensis' $\times$ 'Whasan' (Table S3). Twelve out of the fourteen loci were commonly associated with scab resistance in 2016 and 2018. These common genetic loci, including 11 SNPs and 1 SSR (HB09), were located at the distal end of G6 corresponding to a pseudo-chromosome 6 . Higher LOD scores were confirmed between s6_17037120 and s6_18497564, and the SNP, s6_18497564, displayed higher phenotypic variance for the two years. For that reason, s6_18497564 (54.68 cM) was designated as Rvn3 (Figure 1) with reference to the nomenclature for the apple scab resistance gene [16]. Interestingly, the HB09 was closely linked with Rvn3.

\section{G6}

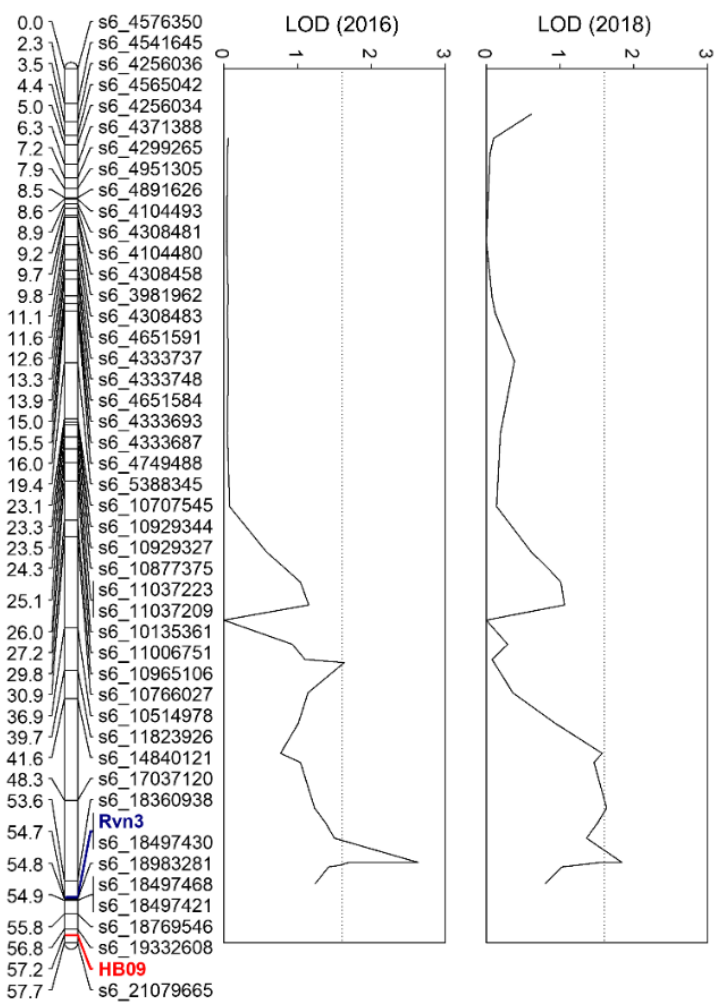

Figure 1. Linkage group (LG) 6 of 'Greensis' (G6) with the novel pear scab resistance gene, Rvn3, highlighted in blue. The number on the left of each marker indicates genetic distance (cM). The red marker is the SSR developed in bacterial artificial chromosome clone of HcrVf2 regarded as candidate for apple scab resistance gene $(V f)$ [17]. The two graphs on the right represent the logarithm of odd (LOD) for each locus in 2016 and 2018.

The LOD thresholds for the other 16 LGs ranged from 1.6 to 1.9 (Figures S3 and S4). There were loci in G3, G8, G13, G14, and G17 where the LOD scores were higher than the LOD threshold in each LG (Figure S3), but these loci were not significant in 2018 (Figure S4).

\subsection{Insertion and Deletion Related with Scab Resistance}

Using the resequencing data of 'Greensis' and 'Whasan', we found insertion and deletion (InDel) structures based on the physical location of the loci significantly associated with scab resistance (Figure 2). The InDel structures of $\sim 1770$ and $\sim 1370$ bp in pseudochromosome 6 were inserted in 'Greensis', while they were deleted in 'Whasan'. The InDel structures of $\sim 1770$ and $\sim 1370$ bp were found around the significant loci s6_17037120 
and s6_21079665, respectively. In the homology analysis using the nucleotide sequences inserted in 'Greensis' (Supplementary file S1), four genes related to disease resistance in apples and pears were identified (Table 2). There was an apple scab resistance gene, namely Malus floribunda clone M18-6Bs Vf apple scab resistance protein HcrVf2-like gene. This gene showed more than $92 \%$ sequence similarity with the partial sequence of the inserted region in 'Greensis'. The remaining two genes were likely serine/threonine protein kinase (XM_029106090.1) and rust resistance kinase Lr10-like (XM_008356659.3) of M. domestica. These two genes covered the InDel sequence of $\sim 280 \mathrm{bp}$, respectively, and showed more than $84 \%$ similarity to the InDel sequences. In addition, there was a disease resistance protein RPM1-like gene with $97.91 \%$ sequence similarity in the InDel structure of $\sim 1370 \mathrm{bp}$.

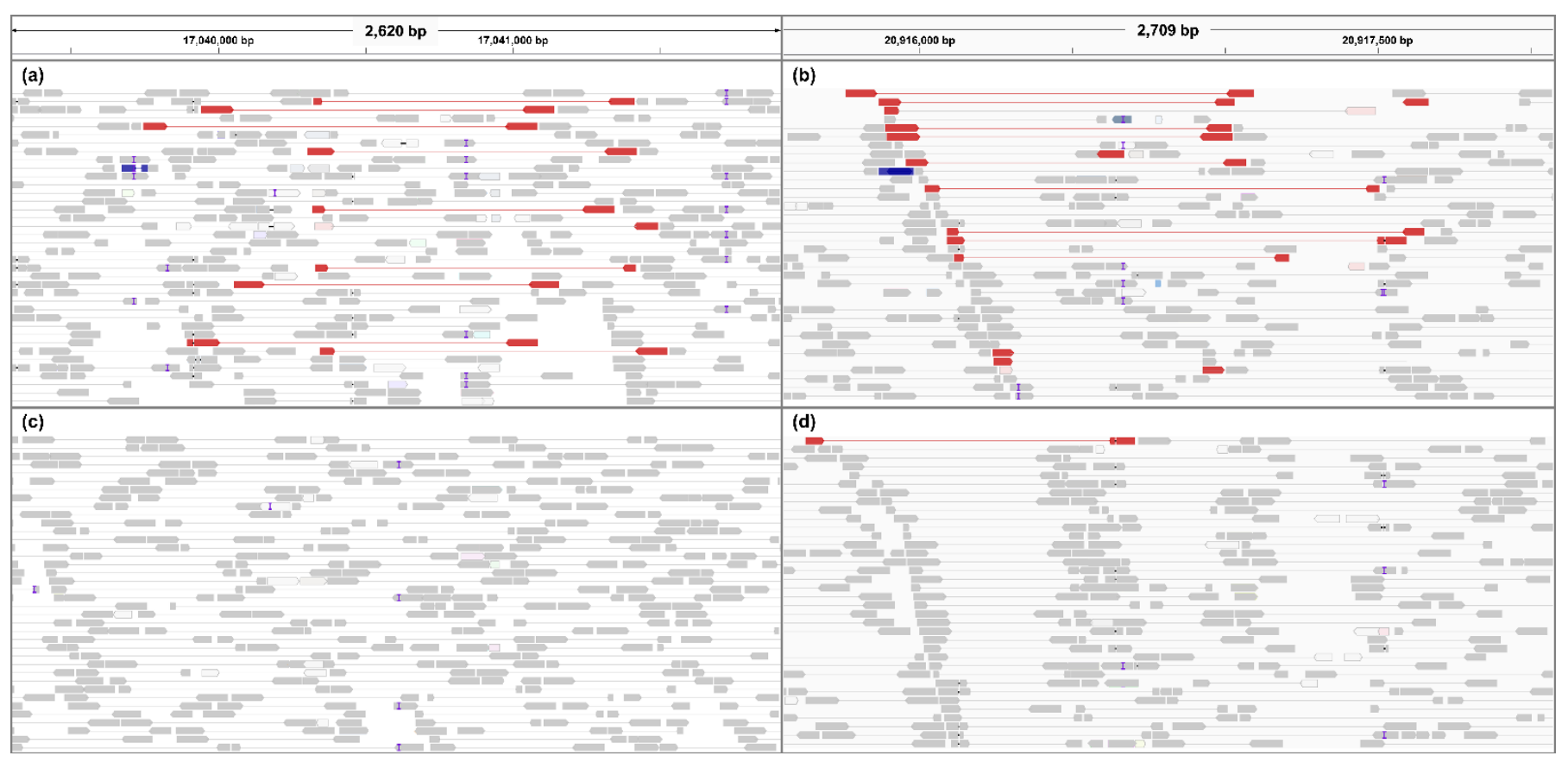

Figure 2. Alignment results of paired reads in 'Greensis' $(\mathbf{a}, \mathbf{b})$ and 'Whasan' $(\mathbf{c}, \mathbf{d})$. Gray reads are a match for the reference genome. Red reads indicate insertions that are larger than expected. Empty reads (colored white) indicate that none of reads are aligned to the reference genome. The 'I' colored purple is a small InDel variation.

Table 2. Results of the sequence similarity analysis of the insertion region in pseudo-chromosome 6 of 'Greensis'.

\begin{tabular}{ccccc}
\hline Gene Description & Accession No. & Query Cover (\%) & E-Value & Similarity (\%) \\
\hline $\begin{array}{c}\text { Malus domestica probable } \\
\text { serine/threonine protein kinase IRE } \\
\text { Malus domestica rust resistance } \\
\quad \text { kinase Lr10-like }\end{array}$ & XM_029106090.1 & 16 & $3.00 \times 10^{-72}$ & 84.42 \\
$\begin{array}{c}\text { Malus floribunda clone M18-6Bs Vf } \\
\text { apple scab resistance protein }\end{array}$ & XM_008356659.3 & 12 & $1.00 \times 10^{-70}$ & \\
$\begin{array}{c}\text { HcrVf2-like gene, complete sequence } \\
\text { Pyrus } \times \text { bretschneideri disease } \\
\text { resistance protein RPM1-like }\end{array}$ & XM_018651218.1 & 89.73 \\
\hline
\end{tabular}

\section{Discussion}

P. communis possesses a single dominant homozygous gene controlling resistance to $V$. nashicola [3]. The pseudo- $\mathrm{BC}_{1}$ was derived from a cross between the scab-resistant cultivar 'Greensis' (P. pyrifolia cv. Whangkeumbae $\times$ P. communis cv. Bartlett) and the scab-susceptible cultivar 'Whasan' (P. pyrifolia). It was assumed that the maternal parent 'Greensis' has inherited $V$. nashicola resistance from its paternal progenitor 'Bartlett'. Therefore, the ratio of resistant to susceptible pseudo- $\mathrm{BC}_{1}$ individuals was expected to be 1:1. 
Evaluating scab resistance in the pseudo- $\mathrm{BC}_{1}$ population indicated that the observed ratio of resistant to susceptible individuals fitted the expected ratio of 1:1 $(p>0.05)$ that was achieved in 2016 and 2018 (Table 1). These results suggest that resistance to V. nashicola in 'Greensis' is controlled by a single dominant gene.

To identify scab resistance loci, genetic linkage maps of maternal and paternal parents were constructed using GBS-SNPs and SSRs (Figures S1 and S2). The physical location of GBS-SNPs allowed us to designate LG as a pseudo-chromosome. Moreover, the anchored SSRs showed co-linearity with previously constructed genetic linkage maps of pear and apple [18-20]. Therefore, our genetic maps partially represent the physical location of the pear genome and they are suitable for comparative analysis between genera.

From the genetic linkage maps and phenotype data assessed for two years, we identified a new Rvn3 conferring resistance to V. nashicola in the LG6 of 'Greensis' (G6) map (Figure 1 and Table S3). The genetic location of the Rvn3 is different from that of the other pear scab $R$ genes (i.e., $V n k$ in LG1 and Rvn2 in LG2), and the pear scab $R$ gene located in LG6 has not been identified until now. However, previously reported pear scab $R$ genes displayed an orthologous relationship with apple scab $R$ genes [4,7]. Furthermore, apple scab $R$ genes located in LG1 and LG6 were considered paralogs [17]. Remarkably, HB09, which is closely linked to the apple scab $R$ gene, Rvi14 [21], is also closely linked to Rvn3 with a genetic distance of $2.5 \mathrm{cM}$ (Figure 1). Broggini et al. [17] developed the HB09 from a bacterial artificial chromosome (BAC) clone, which was isolated from hybridization with HcrVf2, a firstly cloned apple scab $R$ gene [22], and Broggini et al. [17] confirmed that HcrVf2 paralogs were distributed in LG1 and LG6. Therefore, LG6 in pears and apples may contain orthologous $R$ genes to Venturia spp.

To demonstrate the orthologous relationship between the pear and apple scab $R$ genes, the genomic structures of 'Greensis' and 'Whasan' on pseudo-chromosome 6 were compared. As a result, interesting insertions of $\sim 1770$ and $\sim 1370$ bp between mapped SNPs, s6_17037120 and s6_21079665, associated with V. nashicola resistance were detected in the downstream and upstream regions of Rvn3, respectively. The homology between the inserted sequence and HcrVf2 paralog (Table 2) suggested that Rvn3 may be an ortholog of Rvi14.

Interestingly, there were disease-resistance protein RPM1-like sequences in the insertion of $\sim 1370 \mathrm{bp}$. The RPM1 protein is known to activate HR in response to pathogen invasion [23]. Moreover, resistant individuals of the pear pseudo- $\mathrm{BC}_{1}$ ('Greensis' $\times$ 'Whasan') showed two resistant phenotypes, including HR and chlorotic-type reactions. Thus, we thought that the RPM1-like gene could contribute to the control of the scab resistance in 'Greensis'.

In addition, a gene with serine/threonine protein kinase activity was detected in the insertion region. Park et al. [24] and Jiang et al. [25] observed that V. nashicola penetrates the cuticle layer and develops hyphae in the intercellular region. The serine/threonine kinase activity of the intercellular protein kinase domain is one of the characteristics of receptor genes [26,27]. Therefore, it was assumed that certain receptor genes recognize the growth of $V$. nashicola hyphae in the intercellular region, and the protein kinases activate signal transduction in the cytoplasm to confer $V$. nashicola resistance.

Taken together, the novel pear scab resistance gene, Rvn3, was identified in LG6 of the interspecific hybrid pear 'Greensis'. Based on the 1:1 segregation ratio of resistant to susceptible pseudo- $\mathrm{BC}_{1}$ individuals, a single dominant Rvn3 was demonstrated to confer $V$. nashicola resistance. Since the 'Greensis' $\times$ 'Whasan' is a pseudo- $\mathrm{BC}_{1}$ population, based on our findings, the pyramiding strategy will facilitate the breeding of a pear cultivar with durable resistance to $V$. nashicola.

\section{Materials and Methods}

\subsection{Plant Materials}

A pseudo- $\mathrm{BC}_{1}$ population derived from a cross of 'Greensis' (P. pyrifolia $\times$ P. communis, a scab-resistant maternal plant) and 'Whasan' (P. pyrifolia, a scab-susceptible paternal plant) was used in the present study. Seedlings derived from 'Greensis' $\times$ 'Whasan' were grafted on $P$. calleryana and their scab resistance was screened. 


\subsection{Inoculation with V. nashicola and Scoring of Symptoms}

Scab resistance was evaluated in the parents and 93 individuals of 'Greensis' $\times$ 'Whasan' in 2016 and 2018. Using V. nashicola-infected leaves collected in an orchard of the Pear Research Station, National Institute of Horticultural and Herbal Science in Korea $\left(35^{\circ} 01^{\prime} 27.9^{\prime \prime} \mathrm{N}, 126^{\circ} 44^{\prime} 44.5^{\prime \prime} \mathrm{E}\right)$, a V. nashicola conidial suspension $\left(5 \times 10^{5}\right.$ conidia $\cdot \mathrm{mL}^{-1}$, $0.1 \%$ sucrose) was prepared. Droplets of the conidial suspension $(2 \mu \mathrm{L})$ were placed on the upper epidermis of six fully expanded young leaves from two seedlings of each. The droplets were dried, and the inoculated leaves were wrapped in a plastic bag containing $1 \mathrm{~mL}$ of distilled water. The environmental conditions were maintained under the following conditions for $48 \mathrm{~h}: 20^{\circ} \mathrm{C}, 70 \%$ relative humidity, and dark conditions. After that, $16 \mathrm{~h}$ of light periods were held with a light intensity of $108.10 \mu \mathrm{mol} \cdot \mathrm{m}^{-2} \cdot \mathrm{s}^{-1}$. Scab symptoms were evaluated at 6 weeks after inoculation. The symptoms were scored using 5 classes [14,15]: No visible symptoms (1), HR showing pin-point resistance reaction without sporulation (2), chlorotic wrinkled and/or necrotic reaction without sporulation (3), chlorotic reaction with sparse sporulation (4), and abundant sporulation lesion (5). Seedlings, which showed symptoms of classes 1 to 3 , were regarded as scab-resistant. On the other hand, classes 4 and 5 were considered as scab-susceptible symptoms. For subsequent association analysis, the resistant and susceptible individuals were finally scored as 1 and 0 , respectively.

\subsection{Statistical Analysis}

The chi-square test was performed to compare the segregation ratio of resistant to susceptible individuals in the pseudo- $\mathrm{BC}_{1}$ with an expected segregation ratio of $1: 1$ at a $5 \%$ significance level.

\subsection{Linkage and QTL Analysis}

Genetic maps of 'Greensis' and 'Whasan' were constructed using JoinMap 5, and a pseudo-testcross strategy was employed [28]. The genotype data consisting of 5120 GBSSNPs and 89 SSRs for the parent cultivars and their 93 pseudo- $\mathrm{BC}_{1}$ progenies [29] were used. LGs were determined with a minimum LOD threshold of 7.0. The relative distances between markers were calculated by regression mapping and Kosambi's mapping function.

Phenotype and genotype data of pseudo- $\mathrm{BC}_{1}$ individuals were loaded to MapQTL 6. The scab-resistance gene was decided by performing the Kruskal-Wallis test [30] and interval mapping with 1000 permutation tests. The LOD threshold was determined to identify significant loci at $p=0.05$. MapChart 2.3 was applied to visualize genetic linkage maps and the novel scab resistance gene.

\subsection{Resequencing and InDel Detection}

Genomic DNA of 'Greensis' and 'Whasan' was isolated from young leaves using the DNeasy Plant Mini Kit (Qiagen, Hilden, Germany) according to the manufacturer's instructions. DNA libraries with approximately $550 \mathrm{bp}$ of short inserts were constructed using the Truseq DNA PCR-Free kit (Illumina, San Diego, CA, USA) and sequenced with paired-ends using the Illumina Hiseq 2500 platform. Base calling of $101 \mathrm{bp}$ at each end was performed using CASAVA v1.8.2 and the reads were trimmed using SolexQA [31] and Cutadapt [32]. The genome assembly data of P. bretschneideri cv. Dangshansuli v1.1 [33] were used as a reference for the alignment of the trimmed reads. The Burrows-Wheeler Aligner was employed to align the reads [34] using the default option. BAM files were produced using SAMtools [35] and Picard (http:/ / broadinstitute.github.io/picard, Accessed 16 October 2017) [36] to remove PCR duplicates. The BAM files were loaded into the Integrative Genomics Viewer (IGV, [37]) to detect sequence variations between 'Greensis' and 'Whasan'.

Sequences of InDels, which existed in 'Greensis' and 'Whasan' genomes, were extracted in IGV, and homology with public genes was analyzed using the blastn function in the National Center for Biotechnology Information (NCBI). 
Supplementary Materials: The following are available online at https:/ / www.mdpi.com/article/10 .3390/ plants10122632/s1, Figure S1: Genetic linkage map for 'Greensis' (Pyrus pyrifolia $\times$ P. communis). The linkage groups (LGs) of 'Greensis' are designated G1 to G17 and each LG number corresponds to a pseudo-chromosome number of the pear reference genome. The number on the left of each marker indicates genetic distance (cM). Markers highlighted with black are GBS-SNPs. SSRs from pear and apple are highlighted with green and red, respectively, Figure S2: Genetic linkage map for 'Whasan' (Pyrus pyrifolia). The linkage groups (LGs) of 'Whasan' are designated W1 to W17 and each LG number corresponds to a pseudo-chromosome number of the pear reference genome. The number on the left of each marker indicates genetic distance (cM). Markers highlighted with black are GBS-SNPs. SSRs from pear and apple are highlighted with green and red, respectively, Figure S3: Logarithm of odd distributions in the linkage groups of 'Greensis' map. Association analysis was performed using genotype data of 'Greensis' map and phenotypic data evaluated in 2016, Figure S4: Logarithm of odd distributions in the linkage groups of 'Greensis' map. Association analysis was performed using genotype data of 'Greensis' map and phenotypic data evaluated in 2018, Table S1: The number of markers, total genetic distance, and marker density of the linkage group (LGs) in 'Greensis' map, Table S2: The number of markers, total genetic distance, and marker density of the linkage groups (LGs) in 'Whasan' map, Table S3: Pear scab (Venturia nashicola) resistance loci in linkage group 6 of 'Greensis' detected by Kruskal-Wallis test and interval mapping in 2016 and 2018, Supplementary file S1: Two inserted sequences of 'Greensis' detected from resequencing data, Supplementary file S2: Sequence similarity between two InDels detected in 'Greensis' and disease resistance genes described in Table 2 using blastn in National Center for Biotechnology Information.

Author Contributions: S.O. and D.K. designed the whole experiment. S.O. analyzed the overall experiment and wrote the manuscript. H.H. contributed genetic linkage map construction. D.K. managed the experiment and finalized the manuscript. All authors have read and agreed to the published version of the manuscript.

Funding: This work was carried out with the support of "Cooperative Research Program for Agriculture Science and Technology Development (No. PJ015682)" Rural Development Administration, Republic of Korea.

Conflicts of Interest: The authors declare no conflict of interest.

\section{References}

1. Langford, M.H.; Keitt, E.N. Heterothallism and variability in Venturia pirina. Phytopathology 1942, 32, 357-369.

2. Tanaka, S.; Yamamoto, S. Studies in pear scab. II. Taxonomy of the causal fungus of Japanese pear scab. Ann. Phytopathol. Soc. Jpn. 1964, 29, 128-136. [CrossRef]

3. Abe, K.; Kotobuki, K.; Saito, T.; Terai, O. Inheritance of resistance to pear scab from European pears to Asian pears. Hortic. J. 2000, 69, 1-8. [CrossRef]

4. Terakami, S.; Shoda, M.; Adachi, Y.; Gonai, T.; Kasumi, M.; Sawamura, Y.; Iketani, H.; Kotobuki, K.; Patocchi, A.; Gessler, C.; et al. Genetic mapping of the pear scab resistance gene Vnk of Japanese pear cultivar Kinchaku. Theor. Appl. Genet. 2006, 113, 743-752. [CrossRef]

5. Cho, K.H.; Shin, I.S.; Kim, K.T.; Suh, E.J.; Hong, S.S.; Lee, H.J. Development of AFLP and CAPS markers linked to the scab resistance gene, Rvn2, in an inter-specific hybrid pear (Pyrus spp.). J. Hortic. Sci. Biotechnol. 2009, 84, 619-624. [CrossRef]

6. Pierantoi, L.; Dondini, L.; Cho, K.H.; Shin, I.S.; Gennari, F.; Chiodini, R.; Tartarini, S.; Kang, S.J.; Sansavini, S. Pear scab resistance QTLs via a European pear (Pyrus communis) linkage group. Tree Genet. Genomes 2007, 3, 311-317. [CrossRef]

7. Bouvier, L.; Bourcy, M.; Boulay, M.; Tellier, M.; Guérif, P.; Denancé, C.; Durel, C.E.; Lespinasse, Y. A new pear scab resistance gene Rvp1 from the European pear cultivar 'Navara' maps in a genomic region syntenic to an apple scab resistance gene cluster on linkage group 2. Tree Genet. Genomes 2012, 8, 53-60. [CrossRef]

8. Yamamoto, T.; Kimura, T.; Saito, T.; Kotobuki, M.; Matsuta, N.; Liebhard, R.; Gessler, C.; van de Weg, W.E.; Hayashi, T. Genetic linkage maps of Japanese and European pears aligned to the apple consensus map. Acta Hortic. 2004, 6636, 51-56. [CrossRef]

9. Velasco, R.; Zharkikh, A.; Affourtit, J.; Dhingra, A.; Cestaro, A.; Kalyanaraman, A.; Fontana, P.; Bhatnagar, S.K.; Troggio, M.; Pruss, D.; et al. The genome of the domesticated apple (Malus $\times$ domestica). Nat. Genet. 2010, 42, 833-839. [CrossRef]

10. Wu, J.; Wang, Z.; Shi, Z.; Zhang, S.; Ming, R.; Zhu, S.; Awais Khan, M.; Tao, S.; Korban, S.S.; Wang, H.; et al. The genome of the pear (Pyrus bretschneideri Rehd.). Genome Res. 2013, 23, 396-408. [CrossRef]

11. Kim, Y.K.; Kang, S.S.; Won, K.H.; Shin, I.S.; Cho, K.S.; Ma, K.B.; Kim, M.S.; Choi, J.J.; Choi, J.H. Breeding of the scab-resistant pear cultivar 'Greensis'. Korean J. Hortic. Sci. Technol. 2016, 34, 655-661.

12. Iketani, H.; Abe, K.; Yamamoto, T.; Kotobuki, K.; Sato, Y.; Saito, T.; Terai, O.; Matsuta, N.; Hayashi, T. Mapping of disease-related genes in Japanese pear using a molecular linkage map with RAPD markers. Breed. Sci. 2001, 51, 179-184. [CrossRef] 
13. Shin, I.S.; Hyeon, I.H.; Hwang, H.S.; Hong, S.S.; Cho, K.H.; Cho, H.M. Screening of scab (Venturia nashicola) resistance germplasms in Pyrus species. Korean J. Hortic. Sci. Technol. 2004, 22, 63-68.

14. Shay, J.R.; Hough, L.F. Evaluation of apple scab resistance in selections of Malus. Am. J. Bot. 1952, 39, 288-297. [CrossRef]

15. Chevalier, M.; Lespinasse, Y.; Renaudin, S. A microscopic study of the different classes of symptoms coded by the $V f$ gene in apple for resistant to scab (Venturia inaequalis). Plant Pathol. 1991, 40, 249-256. [CrossRef]

16. Bus, V.G.M.; Rikkerink, E.H.A.; Caffier, V.; Durel, C.E.; Plummer, K.M. Revision of the nomenclature of the differential hostpathogen interactions of Venturia inaequalis and Malus. Annu. Rev. Phytopathol. 2011, 49, 391-413. [CrossRef] [PubMed]

17. Broggini, G.A.L.; Galli, P.; Parravicini, G.; Gianfranceschi, L.; Gessler, C.; Patocchi, A. HcrVf paralogs are present on linkage groups 1 and 6 of Malus. Genome 2009, 52, 129-138. [CrossRef] [PubMed]

18. Celton, J.M.; Chagné, D.; Tustin, S.D.; Terakami, S.; Nishitani, C.; Yamamoto, T.; Gardiner, S.E. Update on comparative genome mapping between Malus and Pyrus. BMC Res. Notes 2009, 2, 182. [CrossRef]

19. Terakami, S.; Nishitani, C.; Kunihisa, M.; Shirasawa, K.; Sato, S.; Tabata, S.; Kurita, K.; Kanamori, H.; Katayose, Y.; Takada, N.; et al. Transcriptome-based single nucleotide polymorphism markers for genome mapping in Japanese pear (Pyrus pyrifolia Nakai). Tree Genet. Genomes 2014, 10, 853-863. [CrossRef]

20. Chen, H.; Song, Y.; Li, L.T.; Khan, M.A.; Li, X.G.; Korban, S.S.; Wu, J.; Zhang, S.L. Construction of a high-density simple sequence repeat consensus genetic map for pear (Pyrus spp.). Plant Mol. Biol. Rep. 2015, 33, 316-325. [CrossRef]

21. Soufflet-Freslon, V.; Gianfranceschi, L.; Patocchi, A.; Dure, C.E. Inheritance studies of apple scab resistance and identification of Rvi14, a new major gene that acts together with other broad-spectrum QTL. Genome 2008, 51, 657-667. [CrossRef]

22. Vinatzer, B.A.; Patocchi, A.; Gianfranceschi, L.; Tartarini, S.; Zhang, H.B.; Gessler, C.; Sansavini, S. Apple contains receptor-like genes homologous to the Cladosporium fulvum resistance gene family of tomato with a cluster of genes cosegregating with $\mathrm{Vf}$ apple scab resistance. Am. Phytopathol. Soc. 2001, 14, 508-515. [CrossRef]

23. Zhao, G.; Guo, D.; Wang, L.; Li, H.; Wang, C.; Guo, X. Functions of RPM1-interacting protein 4 in plant immunity. Planta 2021, 253, 11. [CrossRef] [PubMed]

24. Park, P.; Ishii, H.; Adachi, Y.; Kanematsu, S.; Ieki, H.; Umemoto, S. Infection behavior of Venturia nashicola, the cause of scab on Asian pear. Biochem. Cell Biol. 2000, 90, 1209-1216. [CrossRef]

25. Jiang, S.; Park, P.; Ishii, H. Ultrastructural study on scab resistance expressed in epidermal pectin layers of pear leaves. J. Gen. Plant Pathol. 2007, 73, 314-323. [CrossRef]

26. Takemoto, D.; Hayashi, M.; Doke, N.; Nishimura, M.; Kawakita, K. Isolation of the gene for EILP, an elicitor-inducible LRR receptor-like protein, from tobacco by differential display. Plant Cell Physiol. 2000, 41, 458-464. [CrossRef] [PubMed]

27. Yin, Y.; Wu, D.; Chory, J. Plant receptor kinases: Systemin receptor identified. Proc. Natl. Acad. Sci. USA 2002, 99, 9090-9092. [CrossRef] [PubMed]

28. Grattapagli, D.; Sederoff, R. Genetic linkage maps of Eucalyptus grandis and Eucalyptus urophylla using a pseudo-testcross: Mapping strategy and RAPD markers. Genetics 1994, 137, 1121-1137. [CrossRef]

29. Oh, S.; Oh, Y.; Kim, K.; Han, H.; Kim, Y.; Won, K.; Kim, D. Construction of high-resolution genetic linkage map in pear pseudo-BC 1 $(($ Pyrus pyrifolia $\times$ P. communis $) \times$ P. pyrifolia $)$ using GBS-SNPs and SSRs. Hortic. Environ. Biotechnol. 2020, 61, 745-753. [CrossRef]

30. Churchill, G.A.; Doerge, R.W. Empirical threshold values for quantitative trait mapping. Genetics 1994, 138, 963-971. [CrossRef]

31. Cox, M.P.; Peterson, D.A.; Biggs, P.J. SolexaQA: At-a-glance quality assessment of Illumina second-generation sequencing data. BMC Bioinform. 2010, 11, 485. [CrossRef] [PubMed]

32. Martin, M. Cutadapt removes adapter sequences from high-throughput sequencing reads. EMBnet J. 2011, 17, 10-12. [CrossRef]

33. Xue, H.; Wang, S.; Yao, J.L.; Deng, C.H.; Wang, L.; Su, Y.; Zhang, H.; Zhou, H.; Sun, M.; Li, X.; et al. Chromosome level high-density integrated genetic maps improve the Pyrus bretschneideri ‘DangshanSuli' v1.0 genome. BMC Genom. 2018, 19, 833. [CrossRef] [PubMed]

34. Li, H.; Durbin, R. Fast and accurate short read alignment with burrows-wheeler transform. Bioinformatics 2009, 25, 1754-1760. [CrossRef]

35. Li, H.; Handsaker, B.; Wysoker, A.; Fennell, T.; Ruan, J.; Homer, N.; Marth, G.; Abecasis, G.; Durbin, R.; 1000 Genome Project Data Processing Subgroup. The sequence alignment/map format and SAMtools. Bioinformatics 2009, 25, 2078-2079. [CrossRef]

36. Picard. Available online: http:/ / broadinstitute.github.io/picard (accessed on 16 October 2017).

37. Robinson, J.T.; Thorvaldsdóttir, H.; Winckler, W.; Guttman, M.; Lander, E.S.; Getz, G.; Mesirov, J.P. Integrative genomics viewer. Nat. Biotechnol. 2011, 29, 24-26. [CrossRef] 